\title{
Interpretation of Female Images and Character's Destiny in Vanity Fair
}

\author{
Liting Wang ${ }^{1, a}$ \\ ${ }^{1}$ School of Foreign Languages, Anshan Normal University, Anshan 114007, China \\ a597182898@qq.com
}

\begin{abstract}
Keywords: Vanity Fair; female images; character' s destiny
Abstract. Numerous outstanding works were born in British literature in the 19th Century. Among them, Vanity Fair by William Makepeace Thackeray is one of the representative works and even relished by people until today. Female images in it have left a very deep impression on readers and become one of the most notable literary phenomena in the history of British literature. In realistic literature, female images tend to reflect social and family conflicts in that era. They are the best carrier by which the author reveals the society. So this paper attempts to study and expound on female images and character's destiny in Vanity Fair.
\end{abstract}

\section{Introduction}

William Makepeace Thackeray is one of the best realistic writers in the 19th Century and keeps abreast of Charles Dickens in British literature. This is because Thackeray not only creates excellent realistic works, but also makes important theoretical contributions to the concept of novel. His novel Vanity Fair is an epitome of Thackeray' s novel theory and also implies his understanding of the then-existing society. From female images in Vanity Fair, we can catch sight of the inherent contradictions in society and perceive the shaping effect of social environment on human beings. They have a vital significance, long-term artistic value and rich spiritual connotations even in today' s society.

\section{The Composition Background of Vanity Fair}

The complex plots and character setting in Vanity Fair derive from the author' s meticulous observation of life. This is the most precious ability and quality for an excellent writer. Thackeray draws materials from life, adds small potatoes in daily life to the world of Vanity Fair through literary reconstruction and lets readers feel as if they are actually there. There are no heroes or glamorous princess, but infinitely real world. It tells stories that can happen to anyone at any time. This composition technique allows Thackeray to open a new era. In a manner of speaking, Vanity Fair is a miniature of British society in the 19th Century [1].

William Makepeace Thackeray was born in Britain in the 19th Century, which was the most brilliant era in British history. Colonies and trade network across the world brought huge profits to the small island of Britain. Britain became an empire on which the sun never set - a country with the largest territory in human history. However, all these are judgments given by historian when overlooking common people in God's stance. The impression on each person was different. The gap of wealth was widened. The upper class was lapped in luxury, while the poor have to endure exploitation from bureaucrats and businessmen helplessly. The whole society was full of vitality and also confusion. The villeggiatura in agricultural society was destroyed. Industrialized and commercialized society made interpersonal emotions more and more aloof. Human nature was distorted before money. Everyone was frantic for fame and fortune. The society became a big vanity fair [2]. Among those small potato shaped by Thackeray, the ugly face of the entire British upper class was unveiled and no one can pull away from it.

\section{Classic Female Images and Character's Destiny in Vanity Fair}

(I) Viability 
Women' s dignity comes from their independent viability in life. However, in Victorian age, women' s rights were not emancipated. Neither Becky nor Amelia is able to keep a foothold in society on their own. Both of them need to draw support from man' s power, although they have different family backgrounds and also different methods and routes of ups and downs in society.

Becky is supposed to be a woman of great viability. She was born in the lowest rung, clever, quick-witted, understands the rules of society and always wishes to use social rules to achieve her goal. However, these rules are not friendly to a positive woman. Becky is unlikely to become so-called glitterati through her efforts. She can only use a variety of men to achieve her goal. However, this road is also full of frustrations. She shows her desire to marry a rich man returning from India, Joseph, but fails because of his timidity. Later she tries to fall in love with Rawdon, but eventually her marriage with Rawdon doesn' $t$ bring her ideal life but breaks up for Becky turns to pursue other men [3].

Under such social rules, if Becky wants to change her destiny, she must cling to men incessantly. There is no other way out. Her survival depends on men.

While Becky' s classmate Amelia is a pampered young lady from a large estate. She has neither living skills nor a clear understanding of society. She has been set up for life since childhood and takes it for granted. Although misfortunes happen to her later, she still maintains her identity as a genteel lady and turns her son over a rich family which can give him a luxurious upbringing. Amelia is a typical parasite in the patriarchal society [4].

(II) Attitude towards Family and Marriage

Becky and Amelia' s attitudes towards family and marriage also differ a lot. For Becky, the most important thing is to edge herself into the best society and lead an extravagant life. Others are not important. Becky flirts with countless men not because of love. She doesn' t even love her husband. Instead, she fancies entering the uppertendom with the aid of these men. For Becky, love doesn' t make any sense, and marriage is just a means of promotion. She needs to use man' s power to satisfy her desire. The portrayal of the cold-blooded and unsentimental Becky also includes her affections with her son. Becky is pretty and good at singing. But her song has never been heard until her son is 5 years old. It is thus clear that this mother is absolutely unsentimental with her son and has no pity at all when sending him to boarding school. Becky has lost conscience in pursuit of fame and fortune and lost the ability to feel family affections and love.

Amelia is totally different from Becky. She is a canary caged by the patriarchal society. Since she doesn' t have to work and enjoy fruits of man' $\mathrm{s}$ labor, she must completely accept characters and world outlooks imposed by men. As a traditional woman in Victorian age, Amelia doesn' t have a strong heart. Her focus of life is closely related to men, either her father, or her husband, or her son. She loves George whole-heartedly, but George doesn' t cherish this affection. This is because Amelia is too feeble and used to be docile, so all men despise her [5].

Amelia dotes on her son, but has no means of livelihood. As a widow, her life goes from from bad to worse for devoting all the energy to her son. Finally, to enable her son to receive a better life, she sends him to his grandfather. After losing her son, Amelia is like losing everything. That is because she doesn' t have her own life and just lives around others.

Whether Becky or Amelia has to rise and fall with social rules in the patriarchal society and finally accept their pre-established destiny.

(III) Character' s Destiny

When depicting character' s destiny, Thackeray uses a distinct contrast technique. Becky and Amelia are classmates in childhood. They get married and have babies simultaneously. Their husbands go out to battle simultaneously. But these seemingly common life experiences lead to different results. This can only be attributed to their different social classes and characters. Becky always has an ambition to become a top dog and operates her plan carefully. For this plan, she even plays hard and regards marriage as a tool. Amelia, however, doesn' t have her own judgment, but 
receives other people' $s$ arrangement. After losing the source of income, she can' $t$ even live by herself [6-10].

In the final destiny of characters, Becky eventually comes to naught and gets nothing but abandoned by society, while Amelia wins Dobbin' s love. Their distinct destinies highlight the creative intention of Thackeray[11-12]. In this story, both Becky and Amelia are products of the patriarchal society, but Amelia is a rule conformer, while Becky vainly attempts to utilize men, and even challenge man' s authority to realize her dream[13-14]. This is inconsistent with morality in the patriarchal society. Thackeray gives Amelia a promising and good ending, because standing on the position of the patriarchal society, he would more appreciate women like Amelia. Through this ending, he wants to tell everyone that Amelia is the only model. Although she suffers many a setback, she manages to find a reliable man. Of course, finally she has to rely on men. Although such a rule breaker as Becky seems to ride on the crest of success, she would have no good ending.

\section{Conclusion}

Thackeray' s Vanity Fair reveals British society in the 19th Century vividly and lets readers comprehend the oppression of then-existing social system on women deeply. This paper, through an introduction of composition background and analysis of female images and destiny in Vanity Fair, demonstrates the superb literary skills and profound ideological implications in Vanity Fair.

\section{References}

[1] Du, Y. On Gender Difference in the Chinese Versions of Vanity Fair: A Comparative Study of the Translatress Yang Bi's and the Translator Peng Changjiang' s Chinese Versions [D]. Guizhou University, 2008.

[2] Lu, M.Y. Comprehensive Review of 60 Years of Development History and Literary Value of Contemporary Intellectuals Novels [D].Liaoning Normal University, 2011.

[3] Dai, X.L. A Narratological Study on the Rhetorical Art of Faulkner's Absalom Absalom [D]. Shanghai International Studies University, 2012.

[4] Lei, L. On Female Images in Modern War Narrative (1894-1949). [D]. Central China Normal University, 2013.

[5] Zheng, S.J. Study on Flannery O' Connor' s Novels from the Perspective of Freud Psychoanlysis Theory [D]. Tianjin Normal University, 2014.

[6] Hui, C.L. Discussion the Relation of Root and Flower of Character Image between the Moment in Peking and a Dream of the Red Mansion [D]. Yanbian University, 2010.

[7]Tang X J. An analysis on the similarities between "The wuthering heights" and "A dream of red mansion" in terms of love[J]. Journal of Nanchang College of Education, 2010.

[8]Ying H E. On the Thought and Art of Dream of Red Mansion from the Meaning of the Images of the Four Sisters of the Jias[J]. Journal of Changchun Normal University, 2011.

[9]Lin M. Western Ideas and the Development of a New Identity and "Self-Awareness" among Contemporary Chinese Intellectuals[J]. Issues \& Studies, 1996(11):50-66.

[10]Pekar R. The Translatress: The Role of the Feminist Translator[J]. World Literature, 2010(1).

[11]Kang L Y. On Plurality of Interpretation from the Perspective of fusion of horizons: An Analysis of Two Chinese Versions of Vanity Fair[J]. Overseas English, 2014.

[12]Yang S, Yang W. Influence of Ideology, Poetics, Patronage and the Professional on Rewriting Vanity Fair into Chinese Texts[C]// FORUM. 2009:277-298. 
[13]Batty N E. The Riddle of 'Absalom, Absalom!': Looking at the Wrong Blackbird?[J]. Mississippi Quarterly, 1994, 47.

[14]Saunders R. On Lamentation and the Redistribution of Possessions: Faulkner's Absalom, Absalom! and the New South[J]. Mfs Modern Fiction Studies, 1996, 42(4):págs. 730-762. 